DePauw University

Scholarly and Creative Work from DePauw University

8-17-2021

\title{
Marx's inquiry and presentation: The pedagogical constellations of the Grundrisse and Capital
}

Derek R. Ford

DePauw University, derekford@depauw.edu

Follow this and additional works at: https://scholarship.depauw.edu/educ_facpubs

Part of the Education Commons

\section{Recommended Citation}

Derek R. Ford (2021) Marx's inquiry and presentation: The pedagogical constellations of the Grundrisse and Capital, Educational Philosophy and Theory, DOI: 10.1080/00131857.2021.1967741

This Article is brought to you for free and open access by the Education Studies at Scholarly and Creative Work from DePauw University. It has been accepted for inclusion in Education Studies Faculty publications by an authorized administrator of Scholarly and Creative Work from DePauw University. 


\section{Marx's inquiry and presentation: The pedagogical constellations of the Grundrisse and Capital}

\section{Introduction:}

Within the burgeoning literature on learning and studying and their respective relationships to capitalism and communism, there hasn't yet been an examination of Marx's pedagogies as they manifest in his writings. While the revolutionary or disruptive possibilities of studying relative to capitalism and neoliberalism have produced crucial insights (e.g., Ford, 2017b; Lewis and Friedrich, 2016; Malott, 2021; Meyerhoff, 2019), these generally haven't engaged Marx's own pedagogical processes. Elsewhere, I mined Marx's three volumes of Capital for a magical marxist pedagogy (Ford, 2017a). Here, however, I want to turn to Marx's pedagogical constellations of learning and studying as they show up variously in readings of the Grundrisse and Capital, focusing on the distinction between inquiry and presentation, which I translate into distinct educational logics of learning and studying. In doing so, I show both continuities and differences between different readings of both texts, which I argue demonstrate that Marx consistently engaged in and performed both pedagogical logics, but in distinct ways at different times, sometimes as an intentional tactic and others as a contingency of the workers' struggle.

Writing in our neoliberal era, educational scholars have identified the dominance of learning as a key problem in creating a non-capitalist or communist world. Learning is guided by pre-determined ends, upholds binary distinctions between ignorance and intelligence, amateurism and professionalism, students and teachers, and so on. Learning is a developmental process that moves from the former to the latter by various means (constructivist, studentcentered, dialogical, etc.). It is about the actualization of a pre-existing potential. Only on this basis can learning be measured, quantified, and assessed. Learning is attached to productivity, to "immediate utility in daily life" (Lewis and Friedrich, 2016, p. 237). Learning, then, "is more or less a linear process that unfolds chronologically toward maximum outputs" (p. 238).

Studying, on the other hand, encompasses various practices that interrupt, delay, and deactivate learning. While studying, one might have a pre-determined end goal in mind, but that is quickly suspended as the studier finds themselves lost, wandering, and straying in unpredictable and unforeseeable ways. As such, studying is a pedagogical style that renders existing and foreordained ways of being inoperative and, by doing so, it opens up the possibilities of what can be as the dictates of what is are suspended. As one example, Lewis and Friedrich (2016) propose tinkering as a form of studying. While tinkering, the student frees an object or process from any predetermined ends and "the instrumentality" of learning "and the success conditions determining proper vs. improper, success vs. failure are suspended indefinitely" (p. 240). Or, as Weili Zhao (2020) succinctly puts it, the "studier is supposed to forget-suspend its presuppositions and identities, ready to be ex-posed to some signatures hidden sporadically between the lines, evoked to what is unsaid or unresolved aporia, and/or provoked to elaborate the unsaid/aporia toward generating new possibilities" (p. 322).

Learning and studying have been conceptualized as alternative or oppositional logics, yet most scholars agree that there is a necessarily relationship between the two. After all, it is only after learning to read a text that one can study it. For Lewis (2014), studying leaves traces in the product of learning, while for Ford (2016) the task is to navigate between the two processes, a task he assigns to the Communist Party. It may be that the relationship between the two is 
ultimately contingent upon a variety of factors, from the dominant mode of production to the state of the class struggle.

In this paper, I turn to different readings of Marx's writing to excavate his own navigational process, and I do this by focusing on the Grundrisse and Capital and showing how Marx's own distinction between inquiry and presentation isn't so rigid and, as a result, those who argue in favor of one book over the other do so because they fail to recognize his pedagogical tact. I follow Althusser's (1979) notion that "there is no such thing as an innocent reading" (p. 14), and that neither Marx, the interpretations engaged here, nor those that I develop here are objective or neutral. In fact, as Althusser (2006) writes in a later work, it's crucial that Marx was only able to write Capital because of his own experiences in the workers' movement. The sense in which Marx claimed he wasn't a marxist was, as Althusser reminds us, to reject "the idea, 'obvious' to everyone at the time, that he, the individual Marx, the intellectual Marx, could be the intellectual or even political author... For it was the real- the workers' class strugglewhich acted as the true author (the agent)" (18). This is what Marx means when he writes that critical science can only be done by the proletarian class: it isn't Marx but the class struggle that theorizes and, as such, cannot but do so in a strictly partisan manner.

\section{From the Grundrisse to Capital and back again?}

Marx's Grundrisse, a series of notes written in the frantic days of 1857-1858, are seen by some, as preparatory research for his magnum opus, Capital, especially the first volume, the only one published (and republished) during Marx's lifetime. For Louis Althusser (1971), it is Capital that constitutes the one text by which "Marx has to be judged" (p. 45). For others, the notebooks represent a work of Marx in their own right, one that's distinct from and even superior to Capital. Antonio Negri (1991), for example, understands the Grundrisse as an explicitly political text, a more marxist text than Capital precisely because of its "incredible openness" and its emphasis on antagonistic subjectivity (p. 9). Capital, according to Negri, is not only fragmentary but closed, determinate, and objective, a book where antagonisms are resolved dialectically, foreclosing the subjective rupture that communist revolution requires. Others insist that we read them together, not necessarily to provide a final or perfect account of Marxism, but rather because such a co-reading generates new insights. George Caffentzis (2013), for example, insists that the animating forces of communism in the Grundrisse aren't negated in Capital but are rather "mutated in an ingenious way" (p. 270). Taken together, both present different-but not contradictory - aspects of capital's contemporary forms of exploitation and of proletarian forms of resistance.

My intention in this article is not to defend one reading against another to say one is a "correct" versus an "incorrect" interpretation of Marx. In some ways, my wager is that the different presentations are legitimate and productive for the communist struggle. Such a wager, however, is contingent upon an appreciation of Marx's pedagogy, and in particular his heterogenous blocking together of learning and studying. I locate these distinct pedagogical logics in Marx's afterword to the second German edition of the first volume of Capital, where Marx distinguishes the Forschung from the Darstellung, or the practice or method of research from that of presentation. Here Marx is responding to an assessment of Capital that appeared in an 1872 edition of the European Messenger based in St. Petersburg. The assessment focuses on 
Marx's method of presentation and commends Marx for showing the laws of capitalism and of social transformation.

Marx claims this is ultimately an affirmation of his anti-Hegelian dialectic, but before clarifying his dialectic, he briefly notes the necessary differences between inquiry and formulation, a difference I take as pedagogical. "Of course," Marx (1867/1967) writes, "the method of presentation must differ in form from that of inquiry." Inquiry, or what I'm calling studying, "has to appropriate the material in detail, to analyse its different forms of development, to trace out their inner connexion." The method of presentation, or what I'm calling learning, occurs only after this is accomplished. "Only after this work is done," he says, "can the actual movement be adequately described" (p. 28). I argue that Marx is describing two different pedagogies — or educational processes or logics - here.

The first, the method of inquiry, is one that examines material in all of its nuances and relationships, tracing out the different lineages, past, present, and future potential forms of development, and how they each interdepend on and transform each other. As Marx (1939/1973) put it in the 1857 Introduction in the Grundrisse, you move from the world as it is - in our "chaotic conception... of the whole" to transition "from the imagined concrete towards ever thinner abstractions." Yet "from there the journey would have to be retraced" so that the world in its concreteness is "a rich totality of many determinations and relations" (p. 100). This is the pedagogy of studying. Studying or researching is a process that entails wandering around, looking for connections, developing and proposing abstractions and determinations, thinking you're onto something and then following it to a dead end, generating ideas, getting lost in the archives (or on YouTube or the internet), journeying out and wandering or wondering around. When Marx was studying, he had an end in mind: he wanted to understand the inner logics and dynamics of capital, how these came to be, what impact they had and might have on the world, and how the contradictions can be seized during the class struggle.

Only once you've adequately done this can you turn to presenting your findings. The presentation takes a totally different form. It begins with conceptual building blocks and proceeds linearly in a developmental manner. This is why Marx, in Capital, often casts aside the historical beginnings of capitalism and leaves it to the very end, in the last part where we finally learn that it was through slavery, colonialism, legal and extralegal theft, individual and state violence, repression, and so on that capitalism came to be. But he doesn't begin here because he doesn't want us to 1) think this is the complete and global story of how capital came to me; 2) think it's not going on today; and 3) because he simply wants us to understand the inner logic of capitalism as it was most fully developed in England by giving the mainstream politicaleconomists a fair reading.

What you have in Capital is a pedagogy of learning that begins with something simple and obvious (the commodity), and then goes deeper and deeper until we see that this "trivial" appearing thing is a series of ongoing struggles: between and within classes and the state that play out differently over history, that assume different forms (like technology and machinery), and so on. But first we have to get the concept of surplus-value before any of this makes sense, and in order to do that we have to get to the basics of commodities, their two-fold nature, circulation, money, and so on. Learning or presentation, that is, is a developmental process that is more or less linear, advancing from the partial to the complete so that if "done successfully... it may appear as if we had before us a mere a priori construction" (Marx, 1867/1967, p. 28).

Yet Marx's distinction here isn't as firm as it appears. Marx sought to understand, articulate, learn, and relay the precise logics of capital, of its contradictions, and of how the 
working class has and can seize on these contradictions to institute the revolutionary transition to communism. At the same time, he knew he couldn't do this because no one can fully delineate and learn about capitalism so long as it exists, as capital is by definition a dynamic social relation. Andy Merrifield's recent reading of Capital seems to affirm this. Merrifield (2020) writes that "Marx never wanted to finish Capital because he couldn't see how it could ever be finished. He sought the definitive but knew the impossibility of the definitive. It tormented him" (p. 15). Indeed, when one reads the various outlines that Marx presented for Capital in the Grundrisse and elsewhere, it's clear that Marx was taking on a project he knew he could never finish. He wanted to write volumes on the state, the world market, foreign trade, wages, the history of theory, and more. Even in the first volume of Capital, we see traces of Marx's interminable studying in the various places he notes an absolutely crucial point — one we must understand - only to move on and say he can't address it here and it will have to wait until later, until he's returned to studying. Sometimes, like when he brings up credit and rent in volume 1, he does return in volume 3 . But other times, like when he brings up violations of the ideal law of exchanges, he never does because as a pedagogical text, Capital is more developmental.

As a result, Marx's pedagogies of learning and studying should be seen as constellations. Drawing on Walter Benjamin, Lewis (2012) maps out educational marxisms and contends that we should neither defend one at the expense of another nor put them as dots on a timeline unfolding into a completed dialectic synthesis or "final Marxist 'solution.'" Instead, he argues we should approach them as constellations, which don't "resolve tensions within and between competing theories" and instead finds "that such tensions are productive indexes that both connect and disconnect singular theoretical registers" (p. 99). Marx's pedagogical methodsdeployed while writing and researching — are best viewed in this way, as "hang[ing] precariously together, maintaining an absent center" (p. 112). It is not that one subsumes the other or that they eventually transcend their differences in a unity. As this paper shows, both are found together in both the Grundrisse and Capital, although we see different gaps and frictions in each.

Moreover, this paper argues that we shouldn't take different readings of Marx's work as primarily correct or incorrect, siding with one over the other or trying to reconcile their singularities. As such, the argument is fundamentally different from that of David Neilson (2021) who argues that Althusser's reading of Capital "implies mis-reading or non-reading" it (p. 1) as opposed his own which is, according to his own account, "grounded in a critical but faithful interrogation of Marx's texts" (p. 3). To be faithful to Marx is to learn and study not works of Marx's and his interpreters - and most importantly the ongoing history of the international struggle of working and oppressed peoples) — in order to organize and prepare for a revolutionary rupture and build the dictatorship of the proletariat. This doesn't mean there is the absence of polemical debates but rather that such debates are based on revolutionary optimism (Chambers, 2020) that rejects the notion that the masses "are chained and have no power" (p. 4) and that any one particular reading of Marx is "stifling its [marxisms] agency" (Neilson, 2021, p. 3 ). In order to make the strategic shifts and tactical alliances necessary to advance the class struggle, we should maintain the flexibility that constellational thinking allows.

\section{The pedagogies of the Grundrisse}

Marx's pedagogical gestures here testify to the necessity of both educational praxes. Importantly, however, his movements between learning and studying, while sometimes tactical decisions, weren't dictated by some inner genius but by the twists and turns of the workers' movement and, 
undoubtedly, his own health. Marx's serious study of political economy began after the failure of the 1848 bourgeois-democratic revolutions, after which he was exiled to London. He didn't see another uprising on the agenda, and so he set to work studying and writing. While he initially introduced his own political and economic categories with The German Ideology, his serious study didn't begin until much later, in the early 1850s. But when another uprising happened, like the Paris Commune, Marx turned to examine that instead of continuing work on Capital. He pushed the publication of volume 2 because he wanted to see how the early 1970s economic crisis turned out.

Marx's notes that were eventually published as the Grundrisse: Foundations of the Critique of Political Economy (rough draft) were penned during the financial crisis of 1856-7, a crisis that spurred Marx on a frenzy of study. He had a clear goal in mind: to articulate the inner logics and dynamics of capitalism, to critique bourgeois political economy, to lay out a method, and to identify what contradictions could galvanize the revolution. But they were a series of notes, abandoned by Marx and only published first in 1939 in the Soviet Union and made available in Europe and the U.S. during the 1960s-1970s. As notes, they're traces of studying, which, as Eric Hobsbawm (1964) notes, were "written in a sort of private intellectual shorthand which is sometimes impenetrable, in the form of rough notes interspersed with asides which, however clear they may have been to Marx, are often ambiguous to us" (p. 10). As a result, "anyone who has tried to translate the manuscript or even to study and interpret it, will know that it is sometimes quite impossible to put the meaning of some sibylline passage beyond all reasonable doubt" (p. 10). It's for this reason that an edited collection of scholarship on the Grundrisse refers to the book as "a veritable "laboratory" (Bellofiore, Starosta, \& Thomas, 2013, p. 3). Simon Choat's reading emphasizes that the texts were Marx developing concepts, so the notebooks "are dense and elliptical" (p. 1). Because Marx is studying - that is, producing, following, wondering about, and sometimes losing — concepts as he goes, Hobsbawm (1964) says it let us "follow Marx while he is actually thinking" (p. 64).

Negri's 1978 Paris lectures on the Grundrisse, delivered at the invitation of Louis Althusser, represent the most partisan approach to the book. It's not that Negri dismisses Capital, of course, but that he emphasizes the book only represents one aspect of Marxism. The Grundrisse is an endless unfolding of antagonisms produced by and productive of revolutionary subjectivity. Capital, on the contrary, is more limited precisely because of its "categorical presentation" (Negri, 1991, p. 8). Pedagogically speaking, the Grundrisse's traces of studying open more prospects for revolution that the developmental learning of Capital closes down. The difference turns on antagonism and dialectics. The Grundrisse proceeds by way of antagonism, whereas Capital proceeds by way of dialectics (which Negri claims is closed and formulaic). Yet the dialectic for Marx is absolutely crucial in both Capital and the Grundrisse. At the same time, the pedagogical dialectic between learning and studying, for Negri, is incorrectly applied politically in Capital because of its privileging of presentation and learning, while in the Grundrisse is a text of studying that includes learning but prioritizes the class struggle, or the pedagogical form of the Grundrisse is "open on all sides: every conclusion that takes the form of a presentation of the research open spaces to new research and presentation" (p. 12). The text is one in which "the objective analysis of capital and the subjective analysis of class behavior come together, where class hatred permeates his science" (p. 9). Capital, he claims, leaves "no possibility, even in the form of a paradox, of the dynamism of this process by hypostatizing it, by rigidifying it," while "the originality, the happiness, the freshness of the Grundrisse rest entirely 
with its incredible openness" (p. 61). The contradictions of capitalism developed in Capital are replaced in the Grundrisse with antagonism and subjectivity.

The pedagogical form of the Grundrisse, even the presentation or linearity of the logic is a linearity of presentation, but one determined by "a class logic that governs this angle of attack of exposition" (p. 61). The inquiry and presentation of capital is both the antagonism of classes and production of differential production of subjectivity. Yet the motor of difference is based on antagonism and the presentation of the theoretical process of inquiry is "a whole series of operations of the displacement of the subject and the dislocation of the theoretical field" (p. 77). This is because "class struggle does not know synthesis, it only knows victories and defeats" (p. 76). It's a collective knowledge of wins and losses, advances and retreats, which means that Marx's method opens the path to a theory of surplus-value, which isn't a linear intellectual unfolding of a developmental learning but rather a studying that shifts subjectivity and structurally.

This is so because, unlike presentation and learning, reality itself "is not linear" but is rather "transformed continually" as it "draws into its movement the antagonism of collective forces that knowingly exercise power," reality and history continually move the horizon of research. Rather than developmental learning, it's a studying defined by "a qualitative leap," by "collective relations of force" and is thus "not skeptical, but dynamic and creative" (p. 56). And because surplus-value is the essence of capital, this means that capital itself is subjectivity. There is no predetermination, no evolution or unraveling; only a process of studying animated by the indeterminacy and unpredictability of the class struggle. Through disruption and subversion-in thought and practice, in the mind and flesh - new real categories are born and new antagonisms are animated. Negri refers to this as a process of constitution, one that results from antagonistic struggles by different and oppositional subjective forces and that moves from "the relation between the use value of abstract knowledge and the need for a transformation of knowledge" ( $\mathrm{p}$. 47). Such a transformation is the production of reality.

In sum, for Negri what is important in the Grundrisse is not so much the formulation of new categories and concepts, but rather "the definition of social antagonism" (p. 187). The pedagogy that dominates the Grundrisse, on this reading, is one of relentless studying organized around and for communism. Yet it advances, retreats, and suspends the developmental learning at work in the book. In fact, the two pedagogies are constellated together. Marx doesn't finalize one aspect of research and move to the next logical one. Instead, each inquiry uncovers a distinct antagonistic subjectivity and struggle, which renews and compels the formulation of categories and concepts, until the next antagonism displaces the field of studying and learning altogether. Learning here is subordinated to studying insofar as the presentation itself is structured by and productive of antagonism. Whereas the knowledge presented in Capital is fixed and rigid, for Negri, the knowledge of the Grundrisse is open and indeterminate.

\section{The pedagogies of Capital}

While Althusser finds that the texts later compiled as the Economic and Philosophical Manuscripts of 1844 totally idealist, for Althusser (1971) the transitional works "like The German Ideology, or even the Grundrisse" were "very ambiguous", too Hegelian and thus not marxist in their theory, science, philosophy, or praxis (p. 45). The epistemological break or rupture he justifies in For Marx (2005) happens as clarity overtakes ambiguity. The break is twofold: it entails "founding the theory of history (historical materialism)" as well as producing "a 
new philosophy (dialectical materialism)" that happened when he "broke with his erstwhile ideological philosophy" (p. 33). In his later work "Marx in his Limits" Althusser (2006) says the labeling was imprudent but it still rings true. It does so not because of Marx's intellect but as a result of Marx's participation in the organizations and parties of the class, especially the First International, in that these themselves produced the rupture he would later write as Capital (p. 31). Earlier, it's conceived as a break that Marx himself produced that emphasizes clarity.

In his contribution to Reading Capital, Althusser (1979) focuses on the scientific nature of Capital, it's new epistemology and framework that changes the world. While many criticize Althusser's rigidity, I contend that pedagogically and politically Althusser proposes in content and form of Capital that depends on how we engage it. He presents this, I suggest, through two forms of reading-writing. He begins by noting that the book is a series of lecture notes from a class in 1965, which haven't been edited to create (the illusion of?) a completed work, and instead remain "the mere beginnings of a reading," which therefore retain "their rhythm, their didactic or oral style, but also and above all in their discrepancies, the repetitions, hesitations and uncertain steps in their investigations" (p. 13). By doing so, "all the risks and advantages of this adventure are reproduced; so that the reader will be able to find in them new-born the experience of a reading; and so that he in turn will be dragged in the wake of this first reading into a second one which will take us still further" (p. 14). Both kinds of reading-writing and speaking-listening practices block learning and studying together, but the stated goal is clarity for both.

The first practice, however, is not marxist, and occurs when "Marx reads his predecessor's discourse (Smith's for instance) through his own discourse. The result of this reading through a grid... is merely a summary of concordances and discordances, the balances of what Smith discovered and what he missed" (p. 19). This is a reading in which "the logic of a conception of knowledge in which all the work of knowledge is reduced in principle to the recognition of the mere relation of vision; in which the whole nature of its object is reduced to the mere condition of a given" (p. 19). To remain here is to remain trapped in "the mirror myth of knowledge as the vision of a given object or the reading of an established text, neither of which is ever anything but transparency itself' (p. 19). The truth of an object is within the object, and is obtained by abstracting the truth from the object, just like "gold is extracted (or abstracted, i.e., separated) from the dross of earth and sand in which it is held and contained" (p. 38). Here, knowledge's "sole function is to separate, in the object, the two parts which exist in it, the essential and the inessential — by special procedures whose aim is to eliminate the inessential real... and to leave the knowing subject only the second part of the real which is its essence, itself real" (pp. 38-9). The essence is hidden, invisible, and we discover or grasp it in the "most literal sense: removing the covering, as the husk is removed from the nut" (p. 39).

The second reading, which we could call a marxist reading, focuses not on sights and oversights, but the connections or flows between the visible and invisible, and which therefore concerns the possibility of sight itself, in which "non-vision is therefore inside vision, it is a form of vision and hence has a necessary relationship with vision" (p. 22). Hence, we can discover a new conception of knowledge, as against immediate and essential reading, in which the text mirrors knowledge. Instead, we have knowledge and the production of knowledge, the movement of knowledge produced through the flesh of collective subjectivities in struggle. What does the invisible within the visible mean? That writing and reading "can only pose problems on the terrain and within the horizon of a definite theoretical structure, its problematic, which constitutes its absolute and definite conditions of possibility," but moves beyond them at the same time (p. 26). This reading is one in which the eye doesn't see the field, but sees itself 
seeing, or listens to its listening! "It is literally no longer the eye (the mind's eye) of a subject which sees what exists in the field defined by a theoretical problematic: it is this field itself which sees itself in the objects or problems it defines" (p. 26). The invisible isn't the outside of the visible, which would only necessitate an immediate reading of the unread. Instead, "the invisible is defined by the visible as its invisible, its forbidden vision: the invisible is not therefore simply what is outside the visible," "the outer darkness of exclusion-but the inner darkness of exclusion, inside the visible itself because defined by its structure" (p. 27). The limits to the text are internal to it; they represent the traces of study and invite us back to inquiry with its meandering messiness and unpredictable lineages.

This marxist reading doesn't come from "a mental decision to change "view-points"" (28), but instead involves a "real transformation of the means of production of knowledge" ( $p$. 29). Knowledge is something active that's produced through writing and reading. Marx does this through "play" with Hegel, which "is not just raffishness or sarcasm, but the action of a real drama, in which old concepts desperately play the part of something absent which is nameless, in order to call it onto the stage in person" (p. 31). This is like science, which lives, by the extreme attention it pays to the points where it is theoretically fragile" (p. 31). Science isn't about uncovering something that was previously covered, but about listening to silences in the content and the form, perhaps by listening to the nuance or timbre of the matter of writing, which is thought in action.

This approach to reading-writing is philosophical and scientific for Althusser, which means that it questions the relation of the text to its object while questioning the object itself. This entails changing our understandings of fundamental processes, "the 'simplest' acts of existence: seeing, listening, speaking, reading" (p. 16), and revising them against both religious and empiricist readings, summed up as essentialist or immediate readings. Immediate or empiricist reading-writing is that of the Young Marx, who believed that we could know a truth "in black and white" (p. 16) without taking into account the structure in which the text is situated and with which it does its work. Althusser notes that in Capital that Marx's inquiry-study and presentation-learning are again constellated. Marx, he tells us, is above all "a reader who reads to us; and out loud;" Marx "felt the need to fill out his text by reading out loud, not only for the pleasure of quotation, or through scrupulousness in his references... not only because of the intellectual honesty which made him always generously recognize his debts... but for reasons deeply rooted in the theoretical conditions of his work of discovery" (p. 18). This is a doubled reading, with each form operating on different pedagogical logics.

The question is whether each reading produces a more accurate form of knowledge or whether it always entails rendering an opacity transparent. In fact, it does both. We produce knowledge, but there is always a dislocation between the real object and the object of knowledge. As David Backer (2019) writes, "what the theory says is there is never really there: the two are dislocated" (p. 29). Knowledge is circular, in that it produces something that was already there, but we don't merely turn around in the circle "because this circle is not the closed circle of ideology, but the circle perpetually opened by its closures themselves" (Althusser, 1979, p. 75). As Backer (2019) puts it, Althusser's interpretation of Marx's theory of Capital is not only about being open; its distinguishing feature "is that it fights for openness" (p. 52). One way Althusser's writing does this, Backer says, is by employing "scare quotes," which indicates that "the word has competing concepts. In other words, the person who writes the word isn't innocent, nor the person reading it. They work with a problematic that arises out of their moment, experience, and their material situation" (p. 36). They are, in other words, indications of 
ongoing study, of irresoluteness, of the openness of antagonistic materialism and the communist struggle.

We can see another way that Althusser's claims in Reading Capital constellates both pedagogies by his argument that Marx's concepts develop both synchronically and diachronically. Both are forms of presenting and producing knowledge amount to learning, but with different scientific procedures and different knowledge effects. Althusser presents the production and effect of knowledge through two forms: synchronic and diachronic. "Synchrony," he writes, "represents the organizational structure of the concept sin the thoughttotality or system," while "diachrony" is "the movement succession of the concepts in the ordered discourse of the proof" (p. 73). When only read or written synchronically, "the hierarchy of concepts determines to "diachronic order of their appearance" (p. 73). Concepts are presented linearly as building blocks for further concepts. Yet diachrony is when concepts are developed through displacement as they take on different contingencies.

In their application of these scientific procedures, David Kristjanson-Gural (2009) argues that neither can be used without the other without producing errors. The "synchronic error is the failure to take into account the effect of new contingencies on the meaning of the terms within the logical totality at a given moment or level of abstraction," while the "diachronic error results from comparing logical claims at two different moments or levels of analysis without taking into around the different meanings and relationships between concepts that apply at each level" ( $p$. 15). Kristjanson-Gural shows that the synchronic error results in the very notion that that Marx leaves us with a "transformation problem" (e.g., Marx can't account for the transformation of value into price), and the diachronic error results in a total rejection that supply and demand simultaneously "both cannot and must directly affect the value of commodities" because both contradictory claims "belong to distinct stages in the expansion of the logical totality" (p. 28). Both errors occur when only one pedagogical logic is applied; thus the key to Althusser's reading of Capital insists on the dialectical and contingent or tactical deployment of presentation and inquiry. This is why Marx himself blocks them together and never claims to present a unified and ahistorical theory, science, philosophy, or practice.

\section{Conclusion: The open inconclusiveness of Capital}

Negri's critique of Capital is not total in any way. But he insists that the later work's method of presentation - the pedagogy of learning with its developmental logics and seemingly progressive conceptual creations - overtakes and subsumes the method of inquiry - the pedagogy of studying that responds, revives, and displaces such concepts through antagonistic differences within the totality of capital. The class struggle over the working day is replaced by the composition of the organic composition of capital, and the struggle is not defined by exploitation but "on private and competitive capital" rather than "social capital" (p. 27). Capital's categories are "objectified," which "blocks action by revolutionary subjectivity" (p. 8). Even if Capital is organized more along the lines of learning, on my reading there are still traces of antagonistic subjectivity, of differential manifestations of struggle, and the interruption of studying in presentation. There are traces of studying throughout.

One example is the very last chapter of the first volume of Capital, chapter 33. This chapter is concerned with Wakefield's theory of colonialism. It's a rather dry and short chapter, and one that follows from Marx's most succinct case and call for communist revolution, where Marx turns away from the historical empirical inquiry and presents a succinct dialectical and 
historical materialist analysis of the tendency of capitalist accumulation and how the contradictions of capitalism might result in particular revolutionary paths. Marx begins with the scattered private property of individuals in petty manufacture, handicraft, and peasant labor. Together, these prevent the concentration of means of production, division of labor, and cooperation of labor (social labor), the formation of the collective laborer (the antagonistic subject), and so remains locked within the production and circulation of use-values.

Halfway through this first paragraph, Marx (1967) notes that "at a certain stage of development," these property relations create "the material agencies for its own dissolution," producing "new passions" that "the old social organization" prevents (p. 714). Individual private property is annihilated by capital and, through theft, colonialism, slavery, repression, and so on, centralized and concentrated by capital. At the same time, this produces the collective laborer and a social process of work that develops a universal (although not undifferentiated) social worker. As capital concentrates the means of production and the proletarian class, the latter's rebellious nature grows. Capital is now a fetter on production:

The monopoly of capital becomes a fetter upon the ode of production, which has sprung up and flourished along with and under it. centralization of the means of production and socialization of labor at last reach a point where they become incompatible with their capitalist integument. This integument is burst asunder. The knell of capitalist private property sounds. The expropriators are expropriated. (p. 715)

He ends with a speculation on the relative violence of both revolutionary processes. Whereas the centralization and concentration of capital was "incomparably more protracted, violent and difficult than the transformation of capitalistic private property... into socialized property" (p. 715). The former entailed the dispossession, theft, and exploitation of the many by the few, while the latter might entail the expropriation of the few by the many. That's how he ends this brief penultimate chapter. Yet it's not an empirical contradiction but an articulation of contradictions. There's nothing indicating a mechanical or deterministic prediction.

Why not end here? Why end the book with an examination of a rather boring examination of Ebbon Wakefiels' theory of colonialism? One widely accepted answer is that Marx is engaging with Hegel. This is a claim David Harvey introduced in The Limits to Capital and which he still uses to explain the transition. Harvey's (1982) claim is that the chapter is a Hegelian formulation by proposing "colonial solutions" to demonstrate that "there is no outer solution to the internal contradictions of capital" (p. 413).

In the final chapter, Marx appreciates Wakefield's theory for its honesty. Wakefield doesn't try to hide the violence of colonialism or exploitation through notions of equal and free rights. He explicitly acknowledged the need for dispossession. Marx ends volume one by reminding us again that the capitalist mode of production and accumulation are based on expropriation, colonialism, genocide, and slavery. I read this as a return to studying and to the antagonistic class forces that animate marxist theory and practice. Ending with chapter 33, I suggest, implicitly tells us that the contradictions of capitalism - which can't be solved within capitalism — can be pushed back and transformed through colonialism and imperialism. It's an opening to return to studying, to inquiry. The dialectic in chapter 32 may seem teleological and closed, but the brief exposition in chapter 33 undoes that. There are no guarantees, no objective determinants divorced from subjective differences or the class struggle. 
Another example is the famous chapter on the working-day, where Marx announces that "between equal rights force decides" (p. 225). Up until now Marx has taken bourgeois political theory at face value, but here the reality of the struggle forces a leap so that the struggle for a "normal" working day is just that: a struggle between two antagonistic class forces. The chapter presents a narrative of the struggle in England throughout the $19^{\text {th }}$ century, one that's filled with contradictory alliances and betrayals, advances and defeats. It's a struggle waged not by individuals but by collectives: capitalists and workers together through the mediation of the state. Moreover, in a footnote he acknowledges the role that Protestant ideology played in the process "by changing almost all the traditional holidays into workdays" (p. $262 \mathrm{f} 2$ ), and later the role of slavery. There's nothing predictable or deterministic about any of this. This is what we affirm when we say that class struggle is the motor of capitalism and the motor of revolutionary transformation.

Capital and the Grundrisse block together learning and studying differently, but Capital is an open text as well, one that doesn't lock knowledge in place but returns us to a state of suspension, of study. Agamben (1995) makes a connection between studying and stupidity in the Idea of Prose, where he wrote that "those who study are in the situation of people who have received a shock and are stupefied by what has struck them, unable to grasp it and at the same time powerless to leave hold" (p. 64). Without the power to leave the realm of study, the studier remains a state of perpetual wonder. This is not a passive inactivity because of its ceaseless rhythmic sway, a swaying that is itself ceaseless because of the constant deferral of any end point (determinant, expert and conclusive knowledge). Marx returns us to study, as I hope this paper does.

Acknowledgements: Some of the material from this article was originally published in 'Marx's pedagogies then and now: Research and Presentation' on LiberationSchool.org.

\section{References}

Agamben, G. (1995) Idea of Prose, trans. S. Sullivan \& S. Whitsitt SUNY Press, Albany. Althusser, L. (2005). For Marx, trans. B. Brewster. New York: Verso.

Althusser, L. (1979). From Capital to Marx's philosophy. In Louis Althusser and Étienne Balibar, Reading Capital, trans. Ben Brewster (pp. 1-75). New York: Verso.

Althusser, L. (1971). Lenin and philosophy and other essays, trans. Ben Brewster. New York: Monthly Review Press.

Althusser, L. (2006). Marx in His Limits. In L. Althusser, Philosophy of the Encounter: Later Writings, 1978-87, trans. G.M. Goshgarian, ed. Francois Matheron and Oliver Corpet. New York: Verso.

Backer, D.I. (2019). The gold and the dross: Althusser for educators. Boston: Brill.

Bellofiore, R., Starosta, G., \& Thomas, P.D. (2013). Introduction: In Marx's laboratory. In Riccardo Bellofiore, Guido Starosta, and Peter D. Thomas (Eds.), In Marx's laboratory: Critical interpretations of the Grundrisse (pp. 1-14). Rotterdam: Brill.

Caffentzis, G. (2013). From the Grundrisse to Capital and beyond: Then and now." In Riccardo Bellofiore, Guido Starosta, and Peter D. Thomas (Eds.), In Marx's laboratory: Critical interpretations of the Grundrisse (pp. 265-281). Rotterdam: Brill.

Chambers, C.L. (2020). Historical materialism, social change, and the necessity of revolutionary optimism. Human Geography, online first, 1-5. DOI: 10. 1177/ 1942778620977202.

Coat, S. (2016). Marx's 'Grundrisse.' New York: Bloomsbury. 
Ford, D.R. (2016). Communist study: Education for the commons. Lanham: Lexington Books. Ford, D.R. (2017a). Making marxist pedagogy magical: From critique to imagination, or, how bookkeepers set us free. Critical Education, 8(9), 1-13. DOI: 10.14288/ce.v8i9.186183.

Ford, D.R. (2017b). Studying like a communist: Affect, the Party, and the educational limits to capitalism. Educational Philosophy and Theory, 49(5), 452-461. DOI: 10.1080/00131857.2016.1237347.

Harvey, D. (1982). The Limits to Capital. Chicago: University of Chicago Press

Hobsbawm, E.J. (1964). Introduction, in K. Marx, Pre-capitalist economic foundations, ed. E.J. Hobsbawm, trans. Jack Cohen (pp. 9-65). New York: International Publishers.

Kristjanson-Gural, D. (2009). Poststructural logic in Marx's theory of value. Rethinking Marxism, 21(1), 14-33.

Lewis, T.E. (2012). Mapping the constellation of educational Marxism(s). Educational Philosophy and Theory, 44(s1), 98-114.

Lewis, T.E. (2014). The fundamental ontology of study. Educational Theory, 64(2), 163-178.

Lewis, T.E., \& Friedrich, D. (2016) Educational states of suspension. Educational Philosophy and Theory, 48(3), 237-250.

Malott, C.S. (2021). A history of education for the many: From colonization and slavery to the decline of US imperialism. London: Bloomsbury.

Marx, K. (1867/1967). Capital: A critique of political economy (vol. 1), trans. by Samuel Moore and Edward Aveling. New York: International Publishers.

Marx, K. (1939/1973). Grundrisse: Foundations of the critique of political economy (rough draft), trans. by Martin Nicolaus. New York: Penguin Books and New Left Review.

Merrifield, A. (2020) Marx dead and alive: Reading Capital in precarious times. New York: Monthly Review Press.

Meyerhoff, E. (2019). Beyond education: Radical studying for another world. Minneapolis: University of Minnesota Press.

Negri, A. (1991). Marx beyond Marx: Lessons on the Grundrisse, trans. Harry Cleaver, Michael Ryan, and Maurizio Viano. Brooklyn: Autonomedia.

Neilson, D. (2021). Reading Marx again. Educational Philosophy and Theory, online first, 1-4. DOI: 10.1080/00131857.2021.1906648.

Zhao, W. (2020). Calibrating study and learning as hermeneutic principles through Greco-Christian seeing, Rabbinic hearing, and Chinese Yijing observing. Studies in Philosophy and Education, 39(3), 321-336. 